\title{
The Roles of Archive Institution on Indonesia Public Information Disclosure In Digital Era
}

\author{
Okky Rizkyantha \\ orizkyantha@gmail.com
}

\begin{abstract}
Disclosure of Public Information Policy is a form of government awareness regarding the importance of information in determining policy. Disclosure of this information is intended to provide openness for people to take part and supervise the government and institutional policy. Archives institution is known as one of the managers of information which has primary task is to store various important recordings to be used appropriately. This paper aims to analyze the role of archive institution in public information disclosure in Indonesia, and its conduct regarding it. To bridge the needs of the user and archival institutions, it must preset fast and efficient archive service. Act no. 43 of 2007 on Archive is one proof of the role of archive institutions in the digital era. Many laws govern the freedom of information of a person, in terms of security, privacy, and information dissemination. Electronic archive service It is expected to facilitate accesses, and it is also a form of the archive's participation in the Public Information. Although in implementation, there are many issues that archives should face in opening access and disseminating information to the public.
\end{abstract}

Keywords: Archive institution, Disclosure of public information, electronic archive.

\section{Introduction}

The development of information technology has been inescapable, especially since the last two decades. Information used to be difficult to discover, now it has become something that is readily available to the public because 
of the technology. Internet is one of the proofs of technological progress that changed most of human culture. Internet, which contains information that can be accessed by all the people, is the main source of most people in the world in solving the information problem. Information technology is widely used for job management because efficiency and efficiency that have been proven to improve performance, both professional and network. ${ }^{1}$ The easy access, the speed of getting information, can save time and cost, are the attraction of the Internet to be used. So it is not surprising that every human being cannot be separated from the gadgets and the Internet. The Internet as one of the greatest inventions becomes the venue for any digital activity that has now blurred due to the limitations of privacy accessible to anyone.

Each institution attempts to deliver its best performance by providing broad access to information and access. In 2010 the Ministry of Education and Culture applies a system in the form of applications to facilitate monitoring and reporting, known as Basic Education Data (DAPODIK). Education activities and funding in schools must be immediately reported via the internet. And now each institution attempts to provide open-ended information in the various forms such as research results and other scientific results by providing websites and databases that can be accessed, although the fact that can access it freely is the internal parties such as employees, faculty, and its student. And next, how about archive institution, what is it roles on information disclosure in internet era or digital era. It has now changed the format to digital and eases to access via the internet. Ostensibly the largest digital archive, the Internet is in fact a collection or assembly. Primary material-classical sources in the sense of archival documents-are increasingly found on the Net. ${ }^{2}$

Along with the development of information rounds on the Internet, the institution attempted to provide the best information services including

\footnotetext{
${ }^{1}$ Supriyanto, et all, Teknologi Informasi Perpustakaan: Strategi Perancangan Perpustakaan Digital. (Yogyakarta: Kanisius, 2008), 2.

${ }^{2}$ Ernst, Wolfgang, Digital Memory and the Archive, Electronic Mediations, Vol. 39, (London: university of minnesota press, 2013), 85
} 
the government institutions. In Act No. 14 of 2008 on Public Information, more specifically in chapter 3 with the details of the purpose of the law are as follows:

a. To ensure the right of citizens to know the plan of public policy-making, program of public policy, and public decision-making process, as well as the reason for taking a public policy;

b. Encouraging community participation in public policy-making process; increase active role in community public policy, making good management of the public institution;

c. Realizing good governance, which is transparent, effective and efficient, accountable and accountable;

d. Knowing the reasons of public policy that affect the lives of many people;

e. Developing science and intellectual life of the nation; and/or

f. Improve management and service information within public institutions to produce good quality information service. ${ }^{3}$

The government is trying to provide space for the public to monitoring and participate in public policy by making the act of Public Information Disclosure. Then archives institution which is known as a place of important information for both the government and private institution should concern about the information flows and retrieval. Understanding access, information technology, will change at any time, and changes in information technology will have an impact on the accessibility of archives and access requests. Archives as an organizer of important recordings for the public should participate in supporting the law by providing access to information for the public. Services that can be said to be optimal archive if an archive service has wide access and coverage, and can guarantee the security of the archive itself in accordance with the digital era is now demanding efficient and fast-paced. This paper aims to analyze how the roles of archive institution in Information Disclosure, and what archives can do as an information institution in this Public Information Disclosure.

${ }^{3}$ Arsip Nasional Republik Indonesia, Peraturan Kepala Arsip Nasional Indonesia Nomor 28 Tahun 2011 tentang Pedoman Akses dan Layanan Arsip Statis. 


\section{Literature Review}

The basic concept of information disclosure comes from Akerlof, who proposed the concept of asymmetric information. This states that the asymmetric information that exists between both buyers and sellers will generate a so-called "lemons" market. In this, when buyers cannot identify whether a product is good or bad, then they can only base their judgments on the average price. ${ }^{4}$ In Indonesia, The Public Information Disclosure Act was originally named Freedom of Information. Public Information Disclosure Act is one of the national legislative programs of the House of Representatives Initiative 1999 to 2004. The Public Information Disclosure Act was discussed since 1999, after passing the nine-year process, due to the demands of good governance which required accountability, transparency and community participation in every process of public policy implementation of the Public Information Disclosure Laws passed by the House of Representatives on dated April 3, 2008, and enacted on April 30, 2008. ${ }^{5}$ It has been two years to implement this Act. On April 30, 2010, Law Number 14, 2008 on Public Information Disclosure is effective throughout Indonesia. It would take 10 years to enforce the Information Disclosure Guarantee in Indonesia since the amendment 1945 Constitution. In April 2008, it passed into the Public Information Transparency Law. Based on Act No. 14, 2008 on Public Information Disclosure, some objectives of public information disclosure are (1) to ensure the right of citizens to know public policymaking plans, public policy programs and the reasons for public decision making (2) Encourage public participation in the public policy-making process, enhance the active role of communities in public policy making and the management of good public bodies (3) Realizing the implementation of a good state that is transparent, effective and efficient, accountable and can be accounted, Know the reasons for public policy that affect the livelihood of many people (4) Then develop the science and intellectual life of the nation, improving the management

\footnotetext{
${ }^{4}$ Akerlof, George A. (1970). The Market for 'Lemons': Quality Uncertainty and the Market Mechanism. Quarterly Journal of Economics. The MIT Press. 84 (3): 488-500.

${ }^{5}$ Undang-undang No. 14 tahun 2008 tentang Keterbukaan Informasi Publik
} 
and information services environment of public bodies to produce quality information services. ${ }^{6}$

All institution considers the importance of dynamic archive because (a) an agency or individual rely on efficient access to the correct information. Dynamic archive management requires appropriate information for the purposes of (1) assisting decision-making, (2) for public purposes, (3) as evidence of policies and activities, and (4) support litigation. (b) The corporation has legal responsibility, professional, and ethical to create a particular dynamic archive. Body corporations are also required to maintain certain types of dynamic archives or a certain period and this is done by the archives management. (c) The corporation needs to control the volume of information created and save it. This is done for economic reasons the dynamic archive storage of the paper requires a storage room large and operational efficiency reasons. In addition, this recall is more difficult find relevant information if the information is buried on outdated information. ${ }^{7}$

Archive management implemented to maintain the value of the information contained therein. Management must also help provide disclosure of such information to the public. By providing easy access and good services, records as the depositary and managing important information can be a contribution to society. Below are some parts of the Regulation of the National Archives of the Republic of Indonesia Number 28 of 2011 related to the disclosure of information to the public archive, is as follows:

1. The entire archival treasures that exist in the archives are open for public.

2. Against the archives declared closed by the provisions of the legislation or because of other reasons, the head of archival institutions in accordance with the scope of authority may declare the archives be opened after a storage period of 25 years;

3. An archival institution in accordance with the jurisdiction has the authority to establish the openness of the archives prior to 25 years of

${ }^{6}$ Arsip Nasional Republik Indonesia, Peraturan Kepala Arsip Nasional Indonesia Nomor 28 Tahun 2011 tentang Pedoman Akses dan Layanan Arsip Statis.

${ }^{7}$ Basuki, Sulistyo, Pengantar Ilmu Kearsipan, (Jakarta: Universitas Terbuka, 2014), 1.36 
retention stated still covered with consideration. ${ }^{8}$

Despite the disclosure of this information makes it easy for the search of information, but there are some problems related to material, which are accessible and inaccessible. Yuniarti said that an interesting problem though access to the archive has been opened to the public with certain restrictions through a case by case basis, but the manager and the archive is very respectful of the problems regarding private property. ${ }^{9}$ Furthermore, The National Archive of Republic of Indonesia (ANRI) gives descriptions of closed category archives, they are:

1. static Archives about the decision of the Court;

2. Archives of the statutes, regulations, circulars, or any other policy, which does not apply binding or tying into or out as well as consideration of the law enforcement agencies.

3. Archives of the warrant termination of an investigation or prosecution;

4. Archives of the annual spending plan law enforcement;

5. Archives of the annual financial statements of law enforcement agencies;

6. Archives of the report on the refund of the proceeds of corruption;

7. Archives open to the public.

Archives and information Institution now follow and formulate policies related to the Law of the public disclosure. By providing services and access, archive information indicates that the archive is available to the public. And also it is supported by Head of National Archives of Republic of Indonesia Regulation No. 28 of 2011 on the access and archival services. However, there are certain records that are prohibited from accessing the consideration of the information in it can be misused.

${ }^{8}$ Arsip Nasional Republik Indonesia, Peraturan Kepala Arsip Nasional Indonesia Nomor 28 Tahun 2011 tentang Pedoman Akses dan Layanan Arsip Statis.

${ }^{9}$ Yuniarti, F. Materi Pokok Akses dan Layanan Arsip, (Jakarta: Universitas Terbuka, 2007), p.3.3 


\section{Methodology}

The research uses literature study method or literature. The literature study is a method of problem-solving with an in-depth assessment of the problems that have been formulated using the literary aid. ${ }^{10}$ It uses data collection techniques by analyzing books, websites, and scientific papers related to the title. Furthermore, the method of data analysis is a qualitative description, which explains the aspects studied deeply.

\section{Discussion}

\section{Indonesia's Archive on Information Disclosure}

In performing archive static management functions, as it is set in Article 64 paragraph 1 of the Act of the Republic of Indonesia Number 43 of 2009 on Archives set that archival institution are obliged to ensure ease of access for the matter of users. ${ }^{11}$ Accessing archives in archival institutions in accordance with the area of jurisdiction implemented for the benefit of utilization, and public service on the principle of integrity, security, and safety records. An archive access in archival institutions is based on openness and closure in accordance with the provisions of the legislation. In Chapter II of the Regulation of the Archives of the National Republic of Indonesia, number 28 of 2011 says that the obligations of the archive institution include:

a. Providing access and service archives to the archives in a fair/without discrimination, precise, fast, safe, inexpensive, and transparent;

b. Providing access and archival services either directly or indirectly. ${ }^{12}$

Various regulations are set related to information disclosure that must be carried out by institutions especially important information management institutions such as archives. In Law no. Act No. 142008 and Law No. 432009 on Public Information Services State Archive that Public Information created by Archive Creator/Public Agency open to the public

\footnotetext{
${ }^{10}$ Zed, Mestika, Metode Penelitian Kepustakaan, (Jakarta: Yayasan Obor Nusantara, 2008), p.1

${ }^{11}$ Undang-undang No. 43 Tahun 2009 tentang Kearsipan

${ }^{12}$ Arsip Nasional Republik Indonesia, Peraturan Kepala Arsip Nasional Indonesia Nomor 28 Tahun 2011 tentang Pedoman Akses dan Layanan Arsip Statis
} 
is a form of public service (Public Service).$^{13}$ Any records that are stored and maintained by an archive body are publicly owned information so that the Public also has the right to access and use such information properly. Nevertheless, there is some information that is not accessible because it deals with state security affairs. Both laws agree that every institution that has the duty of managing information should contribute to the dissemination of information and provide access to users or the public. The public that is now experiencing a dynamic life then they need to get relevant information related to decision making. It is stated in Chapter II of Law. No. 43 of 2009 on the intent and purpose of archiving at point number 2 is to ensure the availability of authentic and reliable archives as valid evidence. By providing the original and the richest records, archiving always tries to provide reliable information and so does the access privilege of that information. Ministry of Communication and Informatics (KOMINFO) Regulation no. 7 of 2013 states that the Interoperability of Company Documents/State Archives as Public Information created by Archive Creator based on Availability and Integrity. Furthermore, at point 8 is to improve the quality of public services in the management and utilization of authentic and reliable archives. The present use of the archive can be done anywhere, once digitized, the electronic sound or image is open to real-time access and new search options such as similarity-based image retrieval. ${ }^{14}$

The information can be accessed by the entire community in order to resolve the problem. Archive with all the components in it strives to provide information, services, and the best access to the public. The purpose of the public records, including electronic public records, is to serve as a source of authoritative information, authentic and trustworthy, as well as a tool for documenting decisions. Most importantly, this would be evidence of transactions made by the government. This is consistent also with the concept of disclosure public which published by the government through legislation information public disclosure. Basically, archives are publicly accessible

\footnotetext{
${ }^{13}$ Ibid

${ }^{14}$ Ernst, Wolfgang, Digital Memory and the Archive..., 29
} 
information, coupled with the application of technology to the service can add to the information disclosure. Static archives are basically open to the public. Nevertheless, there are some things that cannot be shared with the public for security and public order reasons. As provided in Article 44 of the archiving law that Archive authors may close access to the archive on the grounds that the archive is open to the public may: (1) impede law enforcement; (2) interfere with the interests of the protection of intellectual property rights and the protection of unfair business competition; (3) endangering state defense and security; (4) to disclose Indonesia's natural wealth which is categorized as secrecy; (5) detrimental to national economic resilience; (6) harm the interests of foreign policy and foreign relations; Archives relating to politics and state security should be protected as they may be misused by certain groups and may threaten state security. ${ }^{15}$ Although the information presented is important to the public as a forum for interaction and monitoring of state affairs. Disclosure of information to the plane does not necessarily have limits.

\section{Electronic Archives: Application and Website as effort of openness in Digital} Era

The digital world has been around us, to open its record; archives need to implement the new way of service. By providing the expected archive service, users can get the information. Successful management of archive can be seen from the activities of collecting, processing, and maintenance records can also be seen through the success of our services for user. One of the fast and efficient services that can be provided to the user is an Electronic Archive Services. Read \& Ginn say that electronic record is a record stored on electronic storage media that can be readily accessed or changed, quantitative electronic records may contain the data, text, images, or sounds that originate as an electronic signal. ${ }^{16}$ Electronic records are the records stored on electronic storage media that can be accessed, modified,

\footnotetext{
${ }^{15}$ Undang-udang No. 43 Tahun 2009 tentang Kearsipan

${ }^{16}$ Read, J. \& Ginn, M. L. Record management (9 th. ed.), (Mason, Ohio Thomson SouthWestern, 2011), 1
} 
containing quantitative data, text, pictures, and sound an electronic signal. The advantages of the application of information technology are:

1. Speed Computer can do anything that calculation complex in seconds, very quickly, much faster than can be done by humans.

2. Consistency The result of the processing is more consistent as it does not the format is standardized, although repeatedly done, while humans are difficult to produce exactly the same.

3. Computer precision is not only fast, but also more accurate and right. The computer can detect a very small difference, which cannot be seen with human capabilities and can also perform difficult calculations.

4. What reliability is generated is more reliable than by human beings. The errors that occur are less likely when using a computer. ${ }^{17}$

Indonesia has many institutions that provide archives services through the website, such as archives of the University of Indonesia (arsip.ui.ac.id), Archives of Gajah Mada University (arsip.ugm.ac.id), and east Java Provincial Archive Board (bapersip. jawatimprov.go.id). However, there are still few institutions which have an archive application to support their services. There are still problems that we have to deal with. The need of archives information is still lack. Unlike as library which is used by all people in all ages, archives are used by certain people who really need to use it such as researcher, academics. Many advantages that can be taken by implementing electronic archival services, archival institutions must begin to adapt to the electronic environment in which all records that the institution can be accessed by the user and also as a form of archival institution roles in public and information disclosure. Contemporary archives that engage are not only with images and sounds but also nowadays increasingly with software-based cultural memory (Ernst, 2013). ${ }^{18}$ In becoming a transparent institution, the archive institution attempt to be a public service that opens to information by leaving a service that is technically procedure, a long step, somehow that

\footnotetext{
${ }^{17}$ Suratman. Pengantar Teknologi Informasi. (Jakarta: Bumi Aksara, 2012), 13

${ }^{18}$ Ernst, Wolfgang, Digital Memory and the Archive,..., 9.
} 
create a negative impression to user. Article 64 paragraph (1) of the Law of the Republic of Indonesia No. 43 of 2009 on Archives states that the Archive Institution shall ensure the accessibility of static archives for the interest of archival users. Static archives access to the Archives Institute is based on the nature of openness and closure in accordance with the laws and regulations.

Some business firm has already applied all the easiness of website and application. They give the best way to provide services to their customers. The use of outside agency services can also be considered an institution to manage its archives but, as we know it would require no small amount of having to buy a domain, hired services, and the purchase of the site, and so forth. It all depends on the institution. But certainly, the website of choice for institutions to provide convenience to the user in accessing the existing archives. The electronic environment provides opportunities and challenges to perform the archive function of access and usage. With regards to opportunities, various devices are currently available for remote location and archival access. Thus the role of the archives in information disclosure can be run more widely and quickly. However, some of institutions such as archive province of middle java, BPAD Surakarta, The Government of Surakarta, Government of NAD, Government of Jepara, already used the application to manage their archive even thought is still offline and only can be access on the spot, named SIMARDI (Dynamic Archives Management Information System). They still consider the other things to spend their budget instead of in archive management system. Offline archive system still has a lot of weakness that can't be barriers of efficiency and effectiveness of archive information flow.

Archive management services aim to provide excellence of electronics. And as we all know that every businessman always markets the ideal and best product for tying customers to use the services or products. The growing technology that is accompanied also by the variety of services provided archives bring up the various service innovations that can be used easily. The technology archive will not be accessible if it depends on technological obsolescence. In addition, because information technology provides more power that has ever existed and flexible access and counterfeit tools. To remain 
responsive, the access function must adapt to changes in demand and benefit from technology development. At the same time, the function must ensure the product's authenticity; it will require intellectual control of the archive, the method of providing the archive, and timely response to changes in demand in technology. Android and iOS as the OS platform (Operation System) provides an application container that the user can use. By using mobile devices, service delivery can be done more quickly. The rapid adoption of the mobile environment has engendered the rapid spread of services, which can be seen to have limitations in the existing fixed (stationary) networks such as the web, including social networking services, SNS. ${ }^{19}$

\section{Problems}

Electronic archives with all the advantages it provides also have weaknesses that need to be anticipated. The current disclosure of information already taken into account by various agencies has a great impact in decision making and information dissemination. Because the electronic archive is the output of an information technology system it is necessary to learn more the shortcomings and advantages. Problems that arise are among others: security, privacy, and plagiarism.

\section{Privacy}

The application of technology in the information world creates privacy concerns. Privacy is a person's right to provide or not the information to be accessed. It concerns the right of individuals to retain personal information from access by others who are not authorized to do so. When individual information is publicly available and used then privacy issues are present, privacy is now vulnerable to obscurity. Russel Brown defines the right to privacy as a right born as a result of the right to private property of a particular resource. ${ }^{20}$

\section{Security}

“There is no system impenetrable". That's a phrase we often hear when

${ }^{19} \mathrm{Berg}, \mathrm{M}$, Social intermediaries and the location of agency: a conceptual reconfiguration of social network sites, Contemporary Social Science, Vol. 7 No. 3 2012, pp. 321-333

${ }^{20}$ Brown, Russel, Rethinking Privacy, Alberta Law Review Vol. 43 No. 589, 2006 
watching tech-themed movies. The reality is that every security system has its own weaknesses. By providing public access to the archive, it opens up opportunities to be hacked. Therefore, to keep the archives and database information required, the security is occupied and can be maintained in such a way. There are many things that can threaten a good network that's either an individual who wants to take our own data, which we often call hackers and crackers. We often hear malware words, trojan horses, worms, spyware that can threaten the security of our data on the internet. Some things can be done to avoid data loss due to disaster and other or reduce the occurrence of network attacks such as back-up, install anti-virus applications or firewalls, implement intruder detection, encryption, or authorization systems. Although this security issue is a common problem faced by every technology user and the Internet, One potential reason is providing selective information to present oneself in a positive light or to be seen in a certain way, and the benefit of this may outweigh the costs of possible privacy invasions for social network website users. ${ }^{21}$

\section{Plagiarism}

Digitalization makes it easy to access and get information in an instant way. With this paradigm, there is also the problem of plagiarism which is a frightening specter for every information producer, whether scientific or fiction writer. Copy and paste activity and then given a slight change on it is a common thing when someone plagiarized a work and moreover claimed it as a result of his work. Plagiarism is a separate concern for every information manager. The reason for plagiarism is that which makes the libraries at universities in Indonesia have not dared to open the results of his research freely.

\section{Digital Divide}

Transaction information is now very quickly can be accessed due to most people already use it. But not all people can use the technology. Some

${ }^{21} \mathrm{~J}$ Donath and d boyd, Public displays of connection, BT Technology Journal • Vol 22 No 4 October 2004. 
people who have not been able to feel the convenience is due to the facilities and some people still convince to use the traditional way. This digital divide can result in information inequality that results in traditional perceptions. The people of Indonesia have started realizing the importance of technology in decision making. By 2016, the number of Internet users in Indonesia is 132.7 million users or about $51.5 \%$ of the total Indonesian population of 256.2 million. $^{22}$

\section{Conclusion}

The making of information disclosure law aims to provide freedom of accessing information to the public with the aim of providing transparency and knowledge to the public. Archives institutions that move in the field of information, indirectly have to contribute to it. Law no. 142008 on Public Information Openness directly stipulates that any information available can be accessed by the public. In line with this, archived And furthermore, archives must enhance its services. Archive, with all the components in it, aimed to save the record, organize records, as well as providing services to the users. In line with the aims of the legislation of public access and information which is providing an appropriate service to the user, so that it can be said that an electronic archive service is a form of participation in information disclosure. However, there are things that archive institutions should anticipate such as privacy, security, plagiarism, and the digital divide.

\section{References}

Akerlof, George A. The Market for 'Lemons': Quality Uncertainty and the Market Mechanism. Quarterly Journal of Economics. The MIT Press. 84 (3) 1970: 488-500.

Arsip Nasional Republik Indonesia, Peraturan Kepala Arsip Nasional Indonesia Nomor 28 Tahun 2011 tentang Pedoman Akses dan Layanan Arsip Statis.

${ }^{22}$ Asosiasi Penyelenggara Jasa Internet Indonesia, (2016), Penetrasi dan Perilaku Pengguna Internet di Indonesia. 
Asosiasi Penyelenggara Jasa Internet Indonesia, Penetrasi dan Perilaku Pengguna Internet di Indonesia. 2016.

Sulistyo Basuki, Pengantar Ilmu Kearsipan, Jakarta: Universitas Terbuka, 2014. Berg, M, Social intermediaries and the location of agency: a conceptual reconfiguration of social network sites, Contemporary Social Science, Vol. 7 No. 3 2012, pp. 321-333

Ernst, Wolfgang, Digital Memory and the Archive, Electronic Mediations, Vol. 39, London: university of minnesota press, 2013.

J Donath and d boyd, Public Displays Of Connection, BT Technology Journal - Vol 22 No 4 • October 2004.

Read, J. \& Ginn, M. L. Record management 9 th. ed., Mason, Ohio Thomson South-Western, 2011.

Russel Brown, Rethinking Privacy, Alberta Law Review Vol. 43 No. 589, 2006 Supriyanto, Wahyu dan Ahmad Muhsin. Teknologi Informasi Perpustakaan: Strategi Perancangan Perpustakaan Digital. Yogyakarta: Kanisius, 2008.

Suratman. Pengantar Teknologi Informasi. Jakarta: Bumi Aksara, 2012.

Undang-udang No. 43 Tahun 2009 tentang Kearsipan

Undang-undang no. 14 tahun 2008 tentang Keterbukaan Informasi Publik Yuniarti, F. Materi Pokok Akses dan Layanan Arsip, Jakarta: Universitas Terbuka, 2007.

Zed, Mestika, Metode Penelitian Kepustakaan, Jakarta: Yayasan Obor Nusantara, 2008. 